\title{
The Influence of Landslides Parameters Contributing to Runout Zones using GIS-Based Empirical Model in Kundasang, Sabah
}

\author{
Kamilia Sharir ${ }^{* 1}$, Norbert Simon ${ }^{1}$ and Rodeano Roslee ${ }^{2,3}$ \\ ${ }^{1}$ School of Environment and Natural Resources Sciences, Faculty of Science and Technology, \\ University Kebangsaan Malaysia (UKM), 43600 Bangi, Selangor, Malaysia \\ ${ }^{2}$ Faculty of Science and Natural Resources, University Malaysia Sabah (UMS), \\ Jalan UMS, 88400 Kota Kinabalu, Sabah, Malaysia \\ ${ }^{3}$ Natural Disaster Research Centre (NDRC), University Malaysia Sabah (UMS), \\ Jalan UMS, 88400 Kota Kinabalu, Sabah, Malaysia
}

The study of runout area of landslide enabled us to obtain a spatial prediction for landslides, which could contribute as the basic for the hazard assessment study. This study assesses the influence of terrain parameters that contribute to runout zones using GIS based empirical model in Kundasang, Sabah. The landslide inventories were obtained at 1:12 ooo scales based on interpretation of aerial photographs to identify landslide distributions in three assessment years; 1984, 2009 and 2012. The runout zones were distinguished from the areas within the reach of the mobilized deposits. To estimate the areas that could be affected by the path or deposition of the mobilized materials, a Digital Elevation Model (DEM) with $20 \mathrm{~m} \times 20 \mathrm{~m}$ pixel size was used in the study area. We considered the fact that under intense rainfall events deposits from a landslide tend to travel long distances following the maximum slope and merge with a drainage network. This paper focus on the possible runout flow path distance and affected areas using the TauDEM extension for ArcGIS software starting from the source area to predict deposit area. Parameters such as lithology, soil series and land use influence the runout of landslides, and the transportability of runout flow depends on terrain parameter such as slope angle.

Keywords: Landslide, runout zones, landslide inventory, lndslide hazard assessment, terrain failure parameter

I. INTRODUCTION
The runout area is defined as the area of a landslide that may be reached by all landslide event (Norway Geo. Society, 2015). 
Debris avalanches or flow is a major hazard in mountainous areas and are identified by an extremely high velocities (Crosta et al., 2002). With the help with various modeling tools, the distance and area were calculated for a specific landslide type. The objective of this paper is to investigate the influence of terrain parameters that contribute to runout zones; such as slope angle, lithology, land use and the soil series (soil types).

Given the difficulty of identifying these parameters for future landslide, it is not easy to determine the runout path and the distance reach. However, these problems can be overcome by taking into account the fact that under intense rainfall, of landslide tend to travel long distances following the steepest path and merging with the drainage network (Montgomery and Dietrich, 1994; Pallas et al., 2004; Guinau et al., 2005). As the result from this study, each runout area computed will tend to merge with the nearest drainage system in the study area.

\section{RUNOUT BEHAVIOUR}

Defining the necessary of landslide prediction as the basic for hazard assessment, these require accurate prediction of the runout behaviour of landslide, such as how far and how huge are the runout zones once mobilized. Generally, runout behaviour is a set of quantitative or qualitative spatially distributed parameters that define the destructive potential of a landslide (Dai et al., 2002). These parameters for the purpose of landslide hazard assessment mainly include (Dai et al., 2002; Hungr et al., 1999; Wong et al.,
1997):

- Runout flow path length

- the distance from a landslide source area to the distal toe of the deposition area;

- Damage corridor width

- the width of an area subjected to landslide damage in the distal part of the landslide path;

- Velocity

- how fast the runout travel within the damage corridor which determines the potential damage to facilities and the design parameters of any required protective measures;

- Depth of the moving mass

- the mass from the material in depositional area which influences the impact force of a landslide within the damage corridor; and

- Depth of deposits

- landslides deposits may build up to an enough depth behind a structure to cause it's to disintegrate.

In this study, we are focusing on the runout flow path distance and affected areas as the preliminary for the hazard assessment study. A realistic estimate of runout behaviour of landslide depends on an adequate understanding of the generic factors that control the travel of landslide's deposit. Factors that influence the runout behaviour (slope angle, lithology, land use and the soil series) are also assessed in this paper.

\section{STUDY AREA}


The study area is located in Kundasang, Sabah and was selected because of the abundance of landslides that are often occured either by natural causes or human activities. The study area (Figure 1) covers the latitude of $6^{\circ} 2^{\prime} 27.129^{\prime \prime N}$ $5^{\circ} 54^{\prime} 36.652^{\prime \prime N}$, and longitude of $116^{\circ} 38^{\prime} 35.095^{\prime \prime E}$ - $116^{\circ} 44^{\prime} 40.472 " \mathrm{E}$. The total area coverage is 426km2. Rapid development since the 90's has taken over this area and the development involves many land clearing activities and slope cutting.

The hilly terrain and ridges with an elevation of more than 1500 meters (a.s.l) which happens to be a combination of steep to very steep slopes were a direct after-effect of violent tectonic activities in the past (Tating, 2006; Roslee et al., 2012). The steep and hummocky terrain, regional and unstable local geology, existence of old landslide areas, and intensively geomorphological processes (Roslee, 2012) in the study area, makes it an area prone to landslides. Due to these factors, any construction built on hilly terrain has a higher tendency to landslide occurrences.

The geology of the study area includes the Crocker Formation (Late Eocene to Early Miocence age), Trusmadi Formation (Paleocene to Eocene age), granite intrusion, as well as several recent Quaternary alluvial materials which are still being deposited (Roslee et al., 2008). In general, the Trusmadi Formation exhibits two main structural orientations NW-SE and NE-SW (Tongkul, 2007; Roslee et al., 2008).

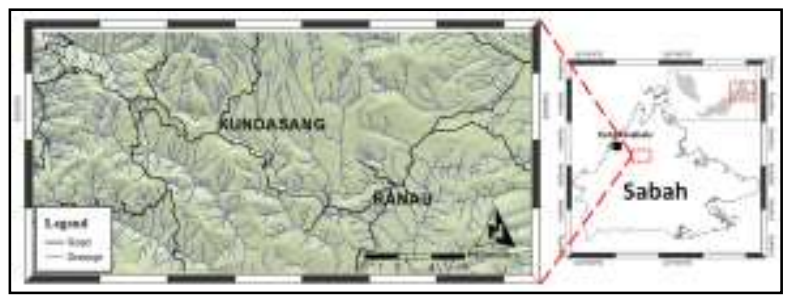

Figure 1: Study area.

The Crocker Formation is divided into four main lithological units which are thickly bedded sandstones, thinly bedded sandstone and siltstone, red and dark shale and slumped deposits, whereas the Trusmadi Formation rock sequence was divided by Jacobson (1970) into four main lithological units, namely; argillaceous rocks, interbedded sequences (turbidites), cataclasites and massive sandstones. The alluvium is limited to the lowland which represents unconsolidated alluvial sediments on river terraces that contain unsorted to well-sorted sand, silt, and clay of varying proportions which are mostly derived from the upstream bed rocks. It occurs as irregular lenses and has a variety of forms and thicknesses.

In areas within Kundasang, landslides could have been conceivably initiated by development, continuous heavy precipitation and earthquakes. These phenomena could be fatal and cause impacts towards societies as well. In a long-term period, they can also contribute towards landscape evolution. By conducting runout analysis of landslides, landslide-susceptible areas can be identified and safer area for development can be delineated. 


\section{M E T H O D S}

According to Dai et al (2001), the runout of the landslide can generally be grouped into three categories. The first includes empirical models aimed at providing practical tools for predicting the runout distance and distribution of landslide debris. The second categories include simplified analytical models, which describe the debris movement in which the debris mass is assumed as a single point. The third includes numerical simulations of conservation equation of mass, momentum, and energy that describe the dynamic motion of debris, and/or a rheological model to describe the material behaviour of debris.

In this study, we are using empirical models as an approach for predicting the runout distance of landslide because empirical methods are generally simple and relatively easy to apply. The information required by these methods is usually general and readily developed. However, empirical methods can only provide a preliminary estimate of the profile.

In this paper, there are two stages of methodologies involved in order to run this analysis; the first stage involves creating a landslide inventory and the second stage is conducting the runout analysis. The prediction of runout model was applied in a GIS environment and compared across three assessment years; 1984, 2009 and 2012.

The first stage involves the identification of the landslide's source zone. In order to identify the source zone, a landslide inventory needs to be produced via the interpretation of aerial photographs. A total of 178 aerial photographs were used to map landslides with the scale of 1:12 ooo throughout three assessment years, starting from 1984, 2009 and 2012.

The interpretation of aerial photographs was mostly done in the Kundasang's area. In order to identify landslides in the aerial photographs, stereo viewing was used. To minimize errors in landslides identification, only landslides with visible scar observed in the photographs were extracted. However, the coverage of the aerial photographs on the study area is different for each year as shown in Figure 2. Unequal coverage of aerial photos is solved by normalizing the area when calculating the landslide runout zone for each parameter classes (landslide frequency/area for each parameter classes).

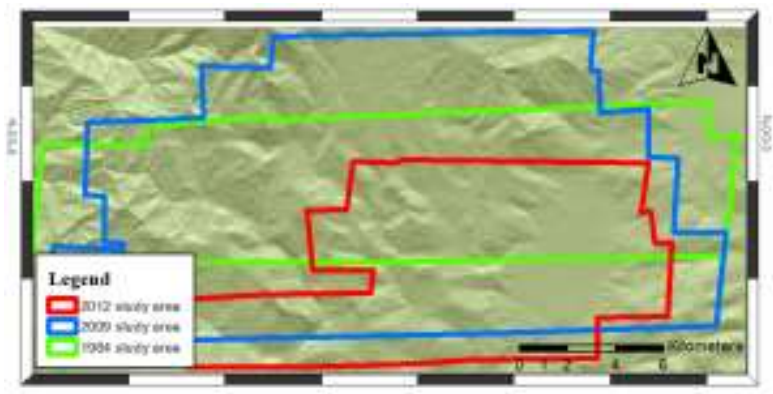

Figure 2: The coverage of the aerial photographs on the study area in different for each assessment years.

The resulting inventory as digitized in ArcMap (ArcGIS) software. In each landslide attribute in the inventory were systematically divided into the scar and the runout zones. In order to carry out a joint analysis of landslides and Digital Elevation Model data, the scar or 
failure zones were rasterized to the DEM resolution in the GIS software. Each failure is assumed to be within a single $20 \mathrm{~m} \mathrm{X} 20 \mathrm{~m}$ pixel (Dai and Lee. 2002; Coe at al., 2004) because $20 \mathrm{~m} \mathrm{X} \mathrm{20m} \mathrm{could} \mathrm{be} \mathrm{optimal} \mathrm{for} \mathrm{analysing}$ landslide source and runout prone areas in the study area.

For the second stage, in order to determine that areas that are prone to landslide, we propose a methodology based on the use of the open source TauDEM software developed by Tarboton (1997). TauDEM is software that can be executed as an ArcGIS extension. This software contains a set of tool which facilitates the assessment of hydrologic processes from DEM (Guinau et al., 2007).

In this study, to identify a landslide affected area and the flow path length, two tools were used: flow direction (D - infinity) and pit removed. Pit remove tool shows the functions of the grid cells surrounded by higher terrain that does not drain. According to Tarboton (1997), pit remove creates a hydrologically correct DEM by raising the elevation of pits to the point where they overflow their confining pour point and can drain to the edge of the domain.
Flow direction is defined as the steepest downward slope on planar triangular facets on a block centred grid (Tarboton, 1997). 'D Infinity multiple flow direction' function was used to assign a multiple numbers of possible flow directions to each pixel based on the direction of the steepest downwards slope (Guinau et al., 2007, Tarboton 1997).

\section{A. Landslide inventory}

The first step of doing a runout analysis is creating a landslide inventory to identifying the landslide source. The landslide inventory was interpreted from aerial photographs and later classified according to Varnes (1978) classification of the landslide. Table 1 summarizes the landslide inventory with the total number of landslides, type of landslide and activity of landslides for each assessment year; 1984, 2009 and 2012. As previously stated, to minimize errors in the landslides identification, only landslides with visible scars observed in the photographs were extracted for the runout analysis.

Table 1: landslide inventory.

\begin{tabular}{|c|c|c|c|c|c|}
\hline \multirow{2}{*}{ Year } & \multirow{2}{*}{ Total landslides } & \multirow[b]{2}{*}{ Average Area $\left(\mathrm{km}^{2}\right)$} & \multicolumn{3}{|c|}{ Type of landslide } \\
\hline & & & Flow & Slide & Complex \\
\hline 1984 & 91 & 1.64 & 35 & 52 & 5 \\
\hline 2009 & 280 & 2.29 & 98 & 182 & 4 \\
\hline 2012 & 62 & 1.35 & 49 & 63 & 6 \\
\hline
\end{tabular}

\section{A. Runout areas}

Three runout zone maps were produced for each assessment year. A total of 58, 161 and 41 
active landslides with clear scar boundary were identified in the 1984, 2009 and 2012 respectively using aerial photographs. These active landslides were used to compute the runout zones. Figure 4 shows the combination of runout zones in the study area across three assessment years.

There are two important things need to be highlighted from the runout zones produced; the distance along the flow paths from the cells in the starting grid to the grid cells in the runout zone and the total number of runout affected in each parameters classes. Each of the runout areas will be used to analyze with the factor influencing the terrain stability.

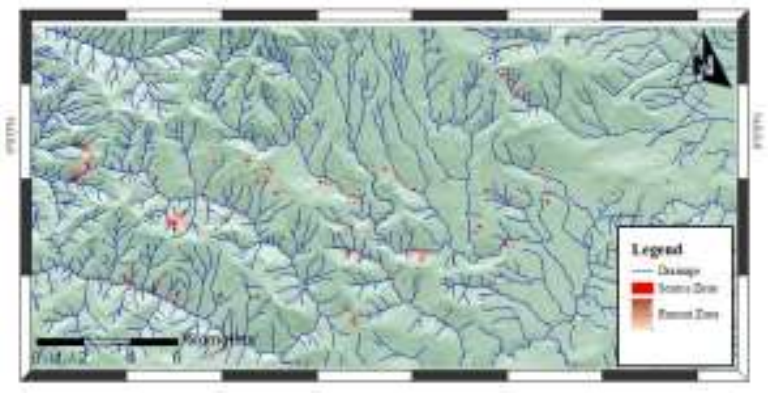

Figure 4: The combination of runout zones in the study area across three assessment years.

Table 2 shows the distance of flow paths across three assesment years and are classified into five categories; <100m, 200m, 300m, $400 \mathrm{~m}$ and $>500 \mathrm{~m}$. From the analysis, the distance of the runout flow path are dominantly fall into $<100 m$ class. The number of runout zones that falls in the "more than 500m' categories that occurred in 1984, 2009 and 2012 are 10, 15 and 3 respectively. It can be considered that any of the runout zones that falls on 'more than 500m' categories be categorized as debris avalanche due to its high in water content and could mobilize the debris far from the source area .

Table 2: the distance along the flow paths from the cells in the starting grid to the grid cells in the runout zone and the area of runout.

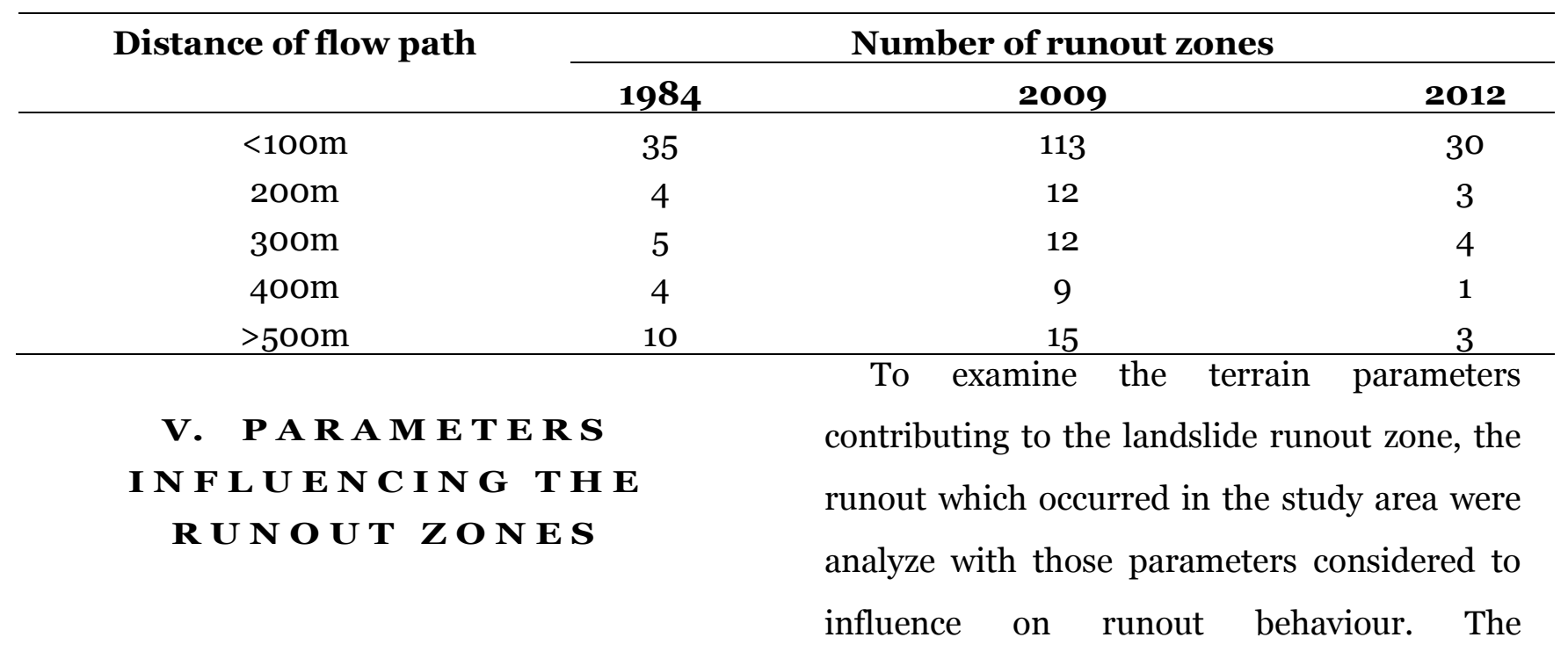


parameters include, slope angle, lithology, soil type and land use. The runout distribution map was crossed with the raster data layer of each parameter which contains different classes. The purpose is to examine the influence of runout behaviour especially on the areas affected and the length of runout. From the model produced across the three assessment years, it can be observed that the longest length runout is over 1 $\mathrm{km}$.

\section{A. Slope angle}

Slope angle has great significance on the susceptibility of a slope to landsliding. To quantify the relative frequency of runout zones on different slope gradients, the slope angle categories was computed using available digital elevation model (DEM) with the cell sized 20m X 20m resolution. The slope angle are classified into four classes according to Department of Mineral and Geoscience Malaysia classification; $<15^{\circ}, 15^{\circ}-25^{\circ}, 25^{\circ}-35^{\circ}$ and $>35^{\circ}$.

Table $3 \mathrm{a}, 3 \mathrm{~b}$ and $3 \mathrm{c}$ show the result of the runout zones in 1984, 2009 and 2012 respectively with slope angle classes. Examination on the number of landslide with the corresponding slope angle categories shows that the distance of the runout zone was highly influenced by the slope angle in the study area. The steeper the slope, the longer the distance of runout zone will travelled. Majority of the runout zone which happen in less than 100m only appeared in slope angle with class less than $<35^{\circ}$ class. The runout which occurred on more than $>400 \mathrm{~m}$ falls in the more than $>35^{\circ}$ class.

Table 3a: 1984

\begin{tabular}{lccccc}
\hline Slope angle & 0-100m & 100-200m & 200-300m & 300-400m & $>$ 400m \\
\hline$<\mathbf{1 5}^{\circ}$ & 19 & 0 & 0 & 0 & O \\
$\mathbf{1 5}^{-2} \mathbf{2 5}^{\circ}$ & 14 & 2 & 2 & 0 & 0 \\
$\mathbf{2 5}-\mathbf{3 5}^{\circ}$ & 2 & 2 & 2 & 2 & 6 \\
$>\mathbf{3 5}^{\circ}$ & 0 & 0 & 1 & 2 & 4 \\
\hline
\end{tabular}

Table 3b: 2009

\begin{tabular}{lccccc}
\hline Slope angle & o-100m & 100-200m & 200-300m & 300-400m & $>$ 400m \\
\hline$<\mathbf{1 5}^{\circ}$ & 65 & 5 & 4 & 0 & 1 \\
$\mathbf{1 5}^{-\mathbf{2 5}^{\circ}}$ & 44 & 6 & 5 & 3 & 2 \\
$\mathbf{2 5}^{\circ} \mathbf{3 5}^{\circ}$ & 4 & 1 & 3 & 4 & 6 \\
$>\mathbf{3 5}^{\circ}$ & 0 & 0 & 0 & 2 & 6 \\
\hline
\end{tabular}

Table 3c: 2012

\begin{tabular}{lccccc}
\hline Slope angle & 0-100m & 100-200m & 200-300m & 300-400m & $>$ 400m \\
\hline$<15^{\circ}$ & 23 & 0 & 0 & 0 & 0 \\
\hline
\end{tabular}




\begin{tabular}{llllll}
\hline $\mathbf{1 5}-\mathbf{2 5}^{\circ}$ & 6 & 0 & 2 & 0 & 0 \\
$\mathbf{2 5}-\mathbf{3 5}^{\circ}$ & 1 & 3 & 2 & 1 & 1 \\
$>\mathbf{3 5}^{\circ}$ & 0 & 0 & 0 & 0 & 2
\end{tabular}

\section{B. Lithology}

The lithological map was grouped into five main lithological classes; "Flysch type sandstone, shale, siltstone with rare tuff, limestone, breccia and agglomerate" (F), "Shale and phyllite with some siltstone and sandstone" (SP), "Acid to intermediate intrunsive: adamellite and granodiorite" (AII), "Terrace sand, gravel and coral" (TS), "Basic to ultrabasic intrunsive: gabbro, dolerite, serpentinite, peridotite, dunite and pyroxenite" (BUI) and "Coastal and riverine alluvium mainly clay, silt and sand” (CRA).

The correlation of the number of runout with lithology is shown in table $4 \mathrm{a}, 4 \mathrm{~b}$ and $4 \mathrm{c}$. It can be seen that throughout the assessment years, there are three lithotype categories with relatively high number of runout zone with the dominant distance of runout less than 100m, namely "Flysch type sandstone, shale, siltstone with rare tuff, limestone, breccia and agglomerate" (F), "Shale and phyllite with some siltstone and sandstone" (SP), and "Terrace sand, gravel and coral" (TS). Besides, it can be seen that runout distance with the length more than $>400$ m falls mostly on the SP lithotype throughout the three assessment years.

The longest runout distance shown by the geological materials in the datasets was in agreement that interbedded rock types especially associated with shale are the most susceptible to landslides (Rib \& Ta, 1978). The interbedded rock type such as the interlayer of sandstone and shale will have different degree of degradation when exposed to weathering. Shale will experience a faster degree of degradation than sandstone, and therefore, will weaken the rock structure and making sandstone easier to slide on top of shale. This is the main causes that make it highly contribute to landsliding.

Table 4a: 1984

\begin{tabular}{lccccc}
\hline Lithology & O-100m & 100-200m & 200-300m & 300-400m & >400m \\
\hline AII & 0 & 0 & 0 & 0 & 0 \\
BUI & 0 & 0 & 0 & 0 & 0 \\
CRA & 10 & 0 & 0 & 0 & 0 \\
F & 9 & 1 & 4 & 1 & 4 \\
SP & 11 & 2 & 1 & 3 & 6 \\
TS & 5 & 1 & 0 & 0 & 0 \\
\hline
\end{tabular}

Table 4b: 2009 


\begin{tabular}{lccccc}
\hline Lithology & O-100m & 100-200m & 200-300m & 300-400m & >400m \\
\hline AII & 0 & 0 & 0 & 0 & 0 \\
BUI & 10 & 1 & 1 & 0 & 3 \\
CRA & 2 & 0 & 0 & 0 & 0 \\
F & 49 & 7 & 9 & 2 & 10 \\
SP & 35 & 2 & 2 & 6 & 1 \\
TS & 17 & 2 & 0 & 1 & 1 \\
\hline
\end{tabular}

Table 4c: 2012

\begin{tabular}{lccccc}
\hline Lithology & 0-100m & 100-200m & 200-300m & 300-400m & >400m \\
\hline AII & 0 & 0 & 0 & 0 & 0 \\
BUI & 3 & 0 & 0 & 0 & 0 \\
CRA & 0 & 0 & 0 & 0 & 0 \\
F & 20 & 3 & 1 & 1 & 2 \\
SP & 5 & 0 & 3 & 0 & 1 \\
TS & 2 & 0 & 0 & 0 & 0 \\
\hline
\end{tabular}

\section{Soil Series}

Soil series is important in providing information about the parent rocks material and physical properties of the soil that contribute to landsliding. From the three assessment years, it can be concluded that Crocker soil type has contributed the most number of runout zones occured in the study area followed by Pinosuk. Most of the runout length of more than $>400$ m occurred in Crocker and Pinosuk soil types. In 2009, Bidu-Bidu type contributed highly to the runout distance which is more than $>400 m$. Figure $5 \mathrm{a}, 5 \mathrm{~b}$ and $5 \mathrm{c}$ shows the correlation between the number of landslide and soil series in each assesment years.
The parent rock for Crocker soil type was made up of sandstone and clay whereas Pinosuk was made up from colluvium and sandstone. Bidu-bidu type was made up from ultrabasic igneous which may disintegrate by weathering process and affect the length of the runout. The sandstone often suffers gully erosion by weathering and rainfall intensity which leads to landsliding. However, these sandstones is part of the cause for gullying and slope movements, the rest being related to slope degrees, rainfall and human activities. With the help of high rainfall intensity, loose material from colluvium may contribute to the runout distance of landslide.

Table 5a: 1984.

\begin{tabular}{lccccc}
\hline Soil series & 0-100m & 100-200m & 200-300m & 300-400m & >400m \\
\hline Bidu Bidu & 10 & 0 & 0 & 0 & 0 \\
\hline
\end{tabular}




\begin{tabular}{lcclll}
\hline Brantian & 0 & 0 & 0 & 0 & 0 \\
Crocker & 10 & 2 & 3 & 2 & 10 \\
Dalit & 0 & 0 & 0 & 0 & 0 \\
Kepayan & 0 & 0 & 0 & 0 & 0 \\
Labau & 3 & 0 & 0 & 0 & 0 \\
Lokan & 2 & 0 & 0 & 0 & 0 \\
Malubok & 0 & 0 & 0 & 0 & 0 \\
Mentapok & 0 & 0 & 0 & 2 & 0 \\
Pinosuk & 5 & 1 & 2 & 0 & 0 \\
Trusmadi & 5 & 1 & 0 & 0 \\
\hline
\end{tabular}

Table 5b: 2009.

\begin{tabular}{lccccc}
\hline Soil series & O-100m & 100-200m & 200-300m & 300-400m & >400m \\
\hline Bidu Bidu & 10 & 1 & 1 & 5 & 7 \\
Brantian & 8 & 0 & 0 & 0 & 0 \\
Crocker & 48 & 7 & 4 & 3 & 3 \\
Dalit & 0 & 0 & 0 & 0 & 0 \\
Kepayan & 4 & 0 & 0 & 0 & 0 \\
Labau & 2 & 1 & 0 & 0 & 0 \\
Lokan & 0 & 1 & 0 & 0 & 0 \\
Malubok & 1 & 0 & 0 & 0 & 0 \\
Mentapok & 0 & 0 & 0 & 1 & 0 \\
Pinosuk & 35 & 1 & 5 & 0 & 5 \\
Trusmadi & 5 & 1 & 2 & 0 \\
\hline
\end{tabular}

Table 5c: 2012

\begin{tabular}{lccccc}
\hline Soil series & 0-100m & 100-200m & 200-300m & 300-400m & >400m \\
\hline Bidu Bidu & 0 & 0 & 0 & 0 & 0 \\
Brantian & 2 & 0 & 0 & 0 & 0 \\
Crocker & 16 & 2 & 3 & 1 & 3 \\
Dalit & 0 & 0 & 0 & 0 & 0 \\
Kepayan & 2 & 0 & 1 & 0 & 0 \\
Labau & 5 & 1 & 0 & 0 & 0 \\
Lokan & 1 & 0 & 0 & 0 & 0 \\
Malubok & 0 & 0 & 0 & 0 & 0 \\
Mentapok & 0 & 0 & 0 & 0 & 0 \\
Pinosuk & 4 & 0 & 0 & 0 & 0 \\
Trusmadi & 0 & 0 & 0 & 0 \\
\hline
\end{tabular}




\section{Land use}

Aerial photographs were used to derived land use maps with the scale of 1:12 ooo throughout in the three assessment years, starting from 1984, 2009 and 2012. The land use were grouped into four main classes; "Built up", "Barren”, "Forest” and "Agriculture". In 1984, barren classes has the highest number of runout zones compare to the other land use class. It contributed 6 runout zone which are more than $>400 \mathrm{~m}$ in length.

The year 2009 shows most of the runout distance with the length that is less than 100m happened in forest area wheareas barren class still contributed to the number of runout which is more than $>400$.

Table 6a: 1984

\begin{tabular}{lccccc}
\hline Land use & 0-100m & 100-200m & 200-300m & 300-400m & >400m \\
\hline Agriculture & 6 & 0 & 0 & 0 & 0 \\
Barren & 10 & 1 & 0 & 0 & 6 \\
Built up & 10 & 2 & 3 & 0 & 2 \\
Forest & 9 & 1 & 2 & 4 & 2 \\
\hline
\end{tabular}

Table 6b: 2009

\begin{tabular}{lccccc}
\hline Land use & O-100m & 100-200m & 200-300m & 300-400m & >400m \\
\hline Agriculture & 11 & 0 & 1 & 1 & 0 \\
Barren & 30 & 2 & 3 & 1 & 11 \\
Built up & 26 & 4 & 1 & 1 & 0 \\
Forest & 46 & 6 & 7 & 6 & 4 \\
\hline
\end{tabular}

Table 6c: 2012

\begin{tabular}{lccccc}
\hline Land use & o-100m & $\mathbf{1 0 0 - 2 0 0 m}$ & $\mathbf{2 0 0 - 3 0 0 m}$ & $\mathbf{3 0 0 - 4 0 0 m}$ & $>$ 400m \\
\hline Agriculture & 0 & 0 & 0 & 0 & 0 \\
Barren & 8 & 0 & 4 & 1 & 0 \\
Built up & 2 & 0 & 0 & 0 & 0 \\
Forest & 20 & 3 & 0 & 0 & 3 \\
\hline
\end{tabular}

\section{D I S C U S S I O N A N D C O N C L U S I O N}

The methodology proposed was to determine areas potentially affected by deposit flow path using the terrain parameters. The TauDEM extension allowed us to identify the flow paths of a runout zone following the steepest track from the potential source area to a drainage network (Guinau et al, 2007). Using this methodology, this software could be a good starting point to determine potential flow paths of the runout from the source zone and is a good way to determine areas prone to 
landslide or debris flow which in turn can help in some way to mitigate landslide hazards.

Certain conditions are required in order for landslides to occur in any specific area. Depositional area of landslide or runout flow transportability depends on terrain parameter such as slope angle, which refers to the maximum slope inclination that rock and soil materials can hold without falling or collapsed. In general, higher slope angle will result in a longer flow path of the landslide runout. Angle varies for different geological materials and conditions.

It may be fair to expect that the properties of the slope-forming materials, such as strength and permeability that involved in the failure, are related to the lithology and soil type, which therefore should affect the likelihood of failure and influenced the flow path distance of the runout from it source area. For the result shown in lithology, it can be seen that the length of runout which is more than $>400 m$ are in lithotypes of "Flysch type sandstone, shale, siltstone with rare tuff, limestone, breccia and agglomerate" (F) and "Shale and phyllite with some siltstone and sandstone" (SP) whereas for soil type it can be seen that throughout the assessment years, Crocker soil type contributed to $>400 \mathrm{~m}$ runout length.

With this study area, the relations of landslide runout zone with the paramaters contributing to the initation of landslides are presented. The parameters choosen are applicable to predict the travel distance of runout and giving adequate information for the hazard assesment of the runout distance when intergrated into map showing slope failure and the digital elevation model (DEM) within GIS.

\section{ACKNOWLEDGMENTS}

This paper presents part of research program funded by the Government of Malaysia under grant (GUP-2014-031 and FRGS/1/2014/STWNo6/UKM/03/1). The authors would also like to acknowledge the support of the staff and facilities at Geology Program, University Kebangsaan Malaysia and University Malaysia Sabah.
[1] Norway Geo Society (2015) Runout-modelling of landslides. https://www.ngu.no/en/topic/run-outmodelling-landslides.

[2] Crosta, G., Imposimato, S., and Roddeman, D. (2002) 'Numerical modelling of large landslide stability and runout', EGS 27th General Assembly, Geophysical Research Abstracts, European Geophysical Society, pp. 4.

[3] Montgomery, D. R. and Dietrich, W. E. (1994) 'A physically based model for the topographic control on shallow landsliding', Water Resour. Res., 30, pp. 1153-1171.
[4] Pall `as, R., Vilaplana, J. M., Guinau, M., Falg `as, E., Alemany, X., and $\mathrm{Mu} \sim$ noz, A. (2004) 'A pragmatic approach to debris flow hazard mapping in areas affected by Hurricane Match: example from NW Nicaragua', Eng. Geol., 72, pp. 57-72.

[5] Guinau, M., Pall `as, R., and Vilaplana, J. M. (2005) 'A feasible methodology for landslide susceptibility assessment in developing countries: A case-study of NW Nicaragua after Hurricane Match', Eng. Geol., 80, pp. 316-327. 
[6] Dai, F. C., Lee, C. F., and Ngai, Y. Y. (2002) 'Landslide risk assessment and management: an overview', Eng. Geol., 64, pp. 65-87.

[7] Hungr, O., Yau, H.W., Tse, C.M., Cheng, L.F., Hardingham, A.D. (1999) 'Natural slope hazard and risk assessment framework'. In: Clarke, B. (Ed.), Urban Ground Engineering. Thomas Telford, London, pp. $332-353$.

[8] Wong, H.N., Ho, K.K.S., Chan, Y.C. (1997) "Assessment of consequence of landslides'. In: Cruden, R., Fell, R. (Eds.), Landslide Risk Assessment. Balkema, Rotterdam, pp. 111 - 149.

[10] Tating F. (2006) 'Geological factors contributing to the landslide hazard area at the Tamparuli - Ranau Highway, Sabah, Malaysia', Proc. of International Symposium on Geotechnical Hazards: Prevention, Mitigation and Engineering Response. Yogyakarta, Indonesia: Utomo, Tohari, Murdohardono, Sadisun, Sudarsono \& Ito, pp 10.

[11] Rodeano Roslee, Mustapa, A. T. \& Tajul, A. J. (2012) 'Landslide management using geospatial technology (LMGT): case study for Kota Kinabalu area Sabah, Malaysia', Prosiding National Geoscience Conference.

[12] Rodeano Roslee, Nor Samihah Abdullah Zawawi, Sanudin Tahir \& S. Abd Kadir S. Omang. (2008) 'Engineering geological study on the slope failure along the Ranau to Tambunan area, Sabah, Malaysia', Proceeding International Conference on Geotech. \& Highway Engineering: GEOTROPIKA 2008.

[13] Tongkul F. (2007) 'Geological inputs in road design \& construction in mountainous areas of West Sabah, Malaysia', Proceedings of the 2nd Malaysia-Japan Symposium on Geohazards \& Geoenvironmental Engineering. Bangi: Institute for Environment \& Development (LESTARI) UKM \& Kyoto University, Bangi, pp. 39-43.

[14] Jacobson, G. (1970) 'Gunung Kinabalu area, East Malaysia', Geol. Surv.Malaysia Rept 8, pp. 111.

[15] Dai, F.C., Lee, C.F. (2001) 'Frequency - volume relation and prediction of rainfall-induced landslides', Engineering Geology 59 (3/4), pp. $253-266$

[16] Coe, J. A., Godt, J. W., Baum, R. L., Bucknam, R. C., and Michael, J. A. (2004) 'Landslide susceptibility from topography in Guatemala', in: Landslides: Evaluation and stabilization, edited by: Lacerda, W. A., Ehrlich, M., Fontura, S. A. B., Sayao, A. S. F., Taylor \& Francis Group, London, 1, pp. 69-78.

[17] Tarboton, D. G. (1997) 'A new method for the determination of flow directions and upslope areas in grid digital elevation models', Water Resour. Res., 33, pp. 309-319.

[18] Guinau, M., Vilajosana, I. and Vilaplana, J. M. (2007) 'GIS-based debris flow source and runout susceptibility assessment from DEM data - a case study in NW Nicaragua', Nat. Hazards Earth Syst. Sci., 7, pp. 703-716.

[19] Varnes, D. J. (1978) 'Slope movement types and prosesses'. In: R \& Schuster. In Special Report 176: analysis and Control. pp. 11-33. Washington: TRB National Research Council.

[20] Dai, F. C. and Lee, C. F. (2002) 'Landslide characteristics and slope instability modelling using GIS, Lantau Island, Hong Kong', Geomorphology, 42, pp. 213-228.

[21] Rib, H. T. and Ta, L. (1978) 'Recognition and identification'. In: R. A. Schuster, landslides analysis and control, special reports 176, pp. 34 - 80. Washington: National Academy of Science. 